rondacks, from Pennsylvania, and from Sudbury, Ont., Canada. At Jackman, Me., it has been found in "open woods and bogs" (Harvey, - Psyche, I897, p. 77). Mr. Scudder states that "it frequents the close branches of the dwarf birch" in the White Mts. Some of my specimens were obtained from birch but most were found on or among the various species of Vaccinium characteristic of the mountain-tops, and on Ascutney among dwarf cornel. It is a somewhat sluggish insect, relying chiefly for protection upon the similarity of its dark olive green coloring to that of the surrounding vegetation, though on warm days the males become fairly active.

\title{
A NEW PARASA, WITH A PRELIMINARY TABLE OF THE SPECIES OF THE GENUS.
}

\author{
BY HARRISON G. DYAR, WASHINGTON, D. C.
}

The Eucleid genera Euclea and Parasa are closely allied and indeed not well separated. There is a stronger tendency to the stalking of vein ro of primaries in Euclea, but some species of Parasa show the same character. Judging from the American larvae alone there appear to be marked differences in the early stages of the genera; but the larva of $P$. lepida, a true Parasa, shows the more generalized Euclea form, proving that our $P$. chloris is a specialized offshoot, not a characteristic type for the genus.

Parasa is a widespread genus, being represented in all the continents except Australia and Europe. The following are its characters :-

Head partially sunken, untufted; palpi upturned, reaching half way to the vertex, third joint small, evenly clothed. Antennae of male pectinated on basal half, the tip simple, the two regions usually sharply marked off, occasionally grading into each other; simple in female. Thorax smoothly haired, not scaly. Abdomen extending moderately beyond hind wings. Legs densely hairy; posterior tibiae with one pair of spurs. Fore wings with the costa straight, rarely convex, outer and inner margins rounded; two internal veins, 2 to 5 rather regularly spaced, 4 and 5 nearest at base ; 6 from cross-vein, 7 to 9 stalked, rarely io also shortly stalked, I from cell, I 2 from base; discal vein often forked and open. Hind wings with three internal veins, 2 to 5 regularly spaced, upper half of cell retracted, 6 and 7 usually stalked, 8 anastomosing with cell toward base with more or less distinct fine veinlets thrown off toward costa.

PARASA PRASINA $n$. $s p$. - Vertex of head and thorax green, a few brown hairs at base of fore wings and a very narrow central 
brown crest. Fore wing green, a small basal dark brown patch, widest on costa, a little angled on median vein and vein I, narrowing to nothing at inner margin. Outer border very narrow, nearly confined to the fringe except between veins 5 to 8 where it widens inwardly; brown, shaded with silvery, edged within by a dark brown line. A very small brown discal dot. Hind wings creamy ocherous, the fringe brown and white. Below uniformly yellowish, fore wings a little greenish, fringe brown tipped. Front of head, palpi and pectus dark brown. Middle and hind legs yellowish. Vein to of fore wings from end of cell. Expanse $25 \mathrm{~mm}$.

Two os without definite locality, but from Mexico or Central America (Heyde). U. S. Nat. Mus., type no. 40r9. Nearest to $P$. imitata Druce. The specimens mentioned in the Biologia Cent. Am., (Lep. Het. II, 44I (1898)), from Costa Rica with hind wings pale cream color may be this species.

In the following synoptic table of Parasa I exclude certain species listed by Kirby. Of these aetitis Wall. and gemmans Feld. belong to Taeda according to Karsch; ancilis Wall. is the type of Ectropa Wall., a genus very distinct from Parasa as I learn from the structural details that Sir G. F. Hampson has kindly sent me; rubriplaga Walk. and unicolor Moore belong to Idonauton and Natada respectively (vide Hampson's Moths of India). Besides these I have excluded provisionally all species without any green marking on the thorax as needing to be reëxamined structurally. They are biguttata Walk., cruda Walk., cupreiplaga Walk., cupreistriga Walk., humilis Mab., vetusta Walk., rubicunda Walk., rudis Walk., pallida Möschl., chlorostigma Snell., and dentata Hamps. The latter species differs in structural characters from Parasa as the male antennae are serrate throughout. I would propose that it be made the type of a new genus, Hampsonella, with the characters given in the "Moths of India."

\section{Synoptic Table of Parasa.}

I. Thorax green, wings without any green marks

Thorax green at least in part, wings with a green band

2. Fore wings shaded with brown broadly at outer margin

Fore wing outwardly marked by a series of intervenular areas

arcuata Karsch (East Africa)

3. Basal space discolorous; expanse $25 \mathrm{~mm}$. lysia Druce (Mexico)

Basal space unicolorous for two-thirds of wing; expanse over $30 \mathrm{~mm}$.

herbifera Walk. (India)

4. A brown spot in the green band at end of cell

No brown discal spot; at most an olivaceous one . . . . 8

5. Outer brown border roundedly waved 6 Outer brown border with an inward point opposite the cell

laranda Druce (Mexico)

6. Thorax brown on the collar

laonome Druce (Mexico)

Thorax all green or a narrow brown crest only . • . • - 7

7. Hind wing brown; outer border of fore wings evenly brown

imitata Druce (Mexico)

Hind wing yellowish; outer border of fore wings washed with white beyond its limiting inner line

prasina Dyar (Mexico) 
8. Thorax brown centrally . . 9 Thorax with a brown spot on each side humeralis Walk. (East Indies) Thorax green throughout, except rarely a fuscous border.

9. A silvery white line bordering the marginal band

No silvery white line

lepida $\mathrm{Cr}$. (India)

ro. Head brown; tegulae with only a small green spot dharma Moore (India) Head green; tegulae all green . II

II. Basal brown area of fore wings present

Basal brown area absent repanda Walk. (India)

argentilinea Hamps. (India)

12. Median green band of fore wings appearing as if constricted centrally . I 3

Median band not appearing constricted I 4

13. Hind wings yellowish; expanse about $60 \mathrm{~mm}$.

chapmani Kirby (C'entral West Africa) vitilena Karsch (Central West Africa)

Hind wings darker on outer third; expanse about $25 \mathrm{~mm}$.

chlorozonata Hamps. (India)

14. Marginal border of fore wings even, not indented; no detached brown specks in the green area . . . . I5

Marginal brown band of fore wings irregular or broken into detached spots

15. Fore wings marked with white . 16 Fore wings not marked with white 18

16. Outer margin brown . . . 17 Outer margin white singularis Butl. (Madagascar)

17. An olivaceous discal dot reginula Saal. (Madagascar) No discal dot valida Butl. (Madagascar)

18. Outer border of fore wing narrow (less than $\frac{2}{10}$ of wing)

Outer border moderate or broad (over $\frac{2}{10}$ of wing)

22

19. Large species (6o mm. expanse)

euchlora Karsch (West Africa)

Moderate sized species ( $35 \mathrm{~mm}$. or less) 20
20. A brown spot in the center of outer band

indetermina Boisd. (No. America)

Outer band uniform . . . 2 I

21. Palpi and legs dark green

Palpi and legs brown

neumanii Karsch. (East Africa) vivida Walk. (South Africa)

22. Margin brown, cut by darker veins and edged within by a darker line . 23

Margin brown with inner and central darker or grayish shades and extending further than usual along the inner margin cebrennis Schaus (Mexico)

Margin brown, marked with a row of lighter lunules within the limiting brown line

zulona Reak (East Indies)

Margin testaceous, edged within by a brown line latistriga Walk. (-)

23. Margin moderately wide $(.21-.26$ length of wing), the included nervules continuously lined in darker brown 24

Marginal border very wide (.4 of surface), the included nervures appearing as if suddenly excised near the margin lorquinii Reak. (East Indies)

24. Under side yellowish

chloris H. S. (North America) minima Schaus (Mexico)

Under side greenish cinereous sinica Moore (China)

25. Abdomen and hind wings green above 26

Abdomen and hind wings yellow or brownish

26. Legs brownish

viridissima Holland (West Africa)

Legs dark green

satura Karsch (West Africa)

27. Basal brown patch present . . 28

Basal brown patch absent on costal edge, above median vein

similis Feld (India and South Africa!)

Basal brown patch absent . $\quad 34$

28. Marginal band brown . . . 31

Marginal band yellow except on the veins $\cdot$..$\quad \cdot \quad \cdot 29$ 
29. Basal patch yellow, covering the cell isabella Moore (India)

Basal patch smaller, not covering over half of the cell . . . . 30

3o. Some red-brown suffusion in the green pastoralis Butl. (India)

No suffusion in the green band consocia Walk. (China)

31. Basal patch broad toward internal margin, dentate a little on median and internal veins $\cdot \quad \cdot \quad \cdot \quad \cdot 32$

Basal patch narrow on internal margin, mostly a costal patch . . . 33

32. Outer border nearly even with dentate projections inward

prussi Karsch (West Africa) punica H. S. (India)

Outer border waved in wardly ebenaui Saal. (Madagascar)

hilaris Westw. (India) ananii Karsch (West Africa) affinis Mab. (Madagascar) urda Druce (West Africa) karschi Dyar* (East Africa)

33. Costa convex, palpi slender; a consider-

* = $\|$ valida Karsch, preoccupied by the Madagascarine species of Butler. able projection of basal patch along median vein; outer border irregular

hilarula Staud. (Asia)

Basal patch without projection; outer border twice curved viridiplena Walk. (Brazil)

34. Narrow terminal border with an enlargement at outer and inner margins. Thorax edged with fuscous . 35

Narrow terminal border entire; some small detached spots in the green field bicolor Walk. (India)

35. A brown patch above the anal angle on outer margin; no white dot

hampsoni Dyar (India)

This patch large between veins 3 to 5 ; a white dot in patch on inner margin albipuncta Hamps. (India)

Note. - Where more than one species occurs under the same heading, I have not been able to separate them satisfactorily with the material at hand. Species not placed, hilarata Staud. (Asia). The species at the end of the table must closely resemble Taeda. If they were not placed in Parasa by Hamp. son without indication of different structure, I should question the generic reference.

Guide to the Genera and Classification of the Orthoptera of North America north of Mexico. By Samuel H. Scudder. $90 \mathrm{pp} .8^{\circ}$.

Contains keys for the determination of the higher groups as well as the (nearly 200) genera of our Orthoptera, with full bibliographical aids to further study. Sent by mail on receipt of price $(\$ \mathrm{r} .00)$.

E. W. WheEler, 30 Boylston Street, Cambridge, Mass.

\section{A. SMITH \& SONS, 269 PEARL STREET, New York.}

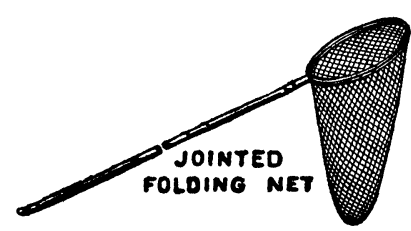

GOODS FOR ENTOMOLOGISTS,

Klaeger and Carlsbad Insect Pins, Setting Boards, Folding Nets, Locality and Special Labels, Forceps, Sheet Cork, Esc. Other a rticles are being added, Send for List. 

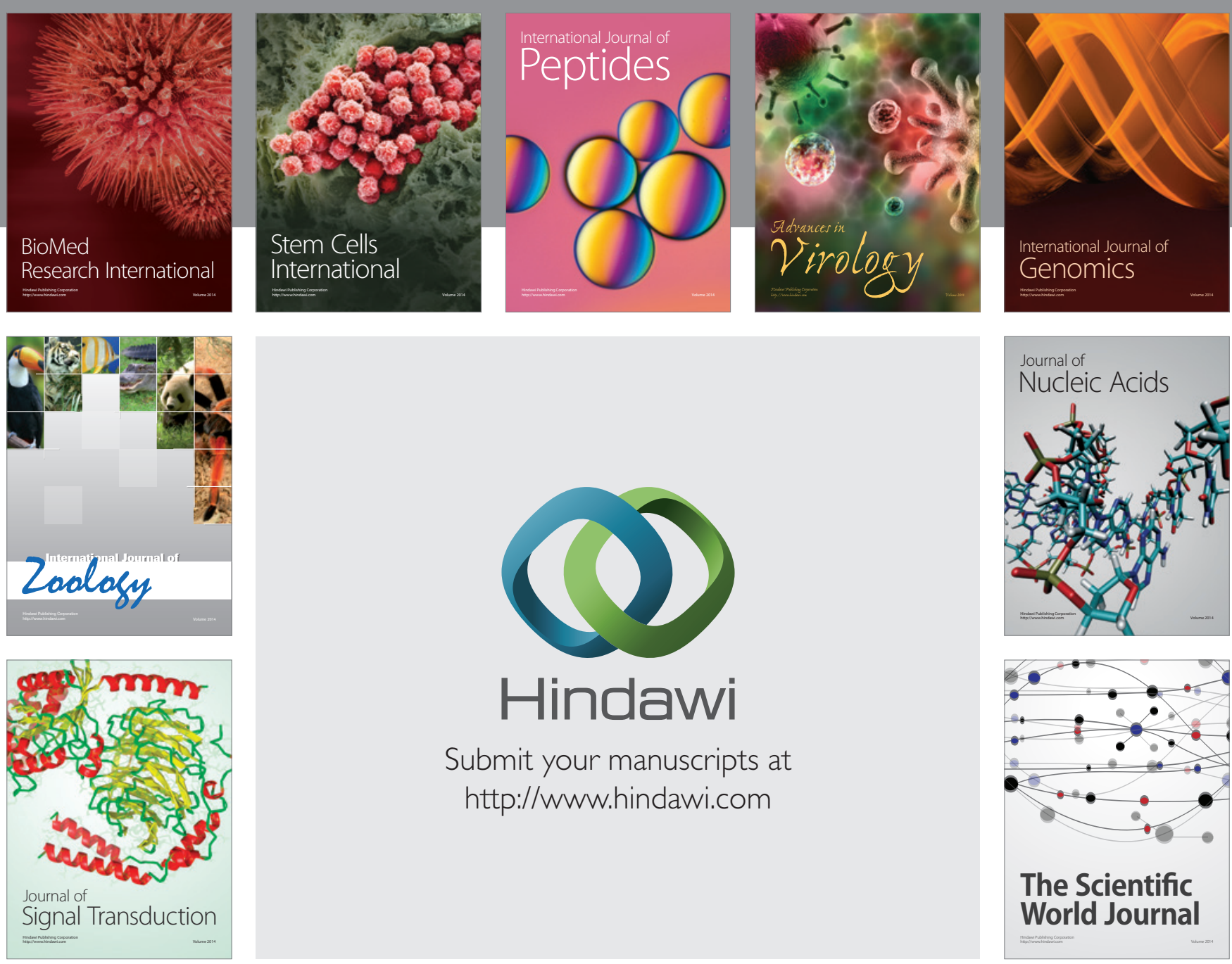

Submit your manuscripts at

http://www.hindawi.com
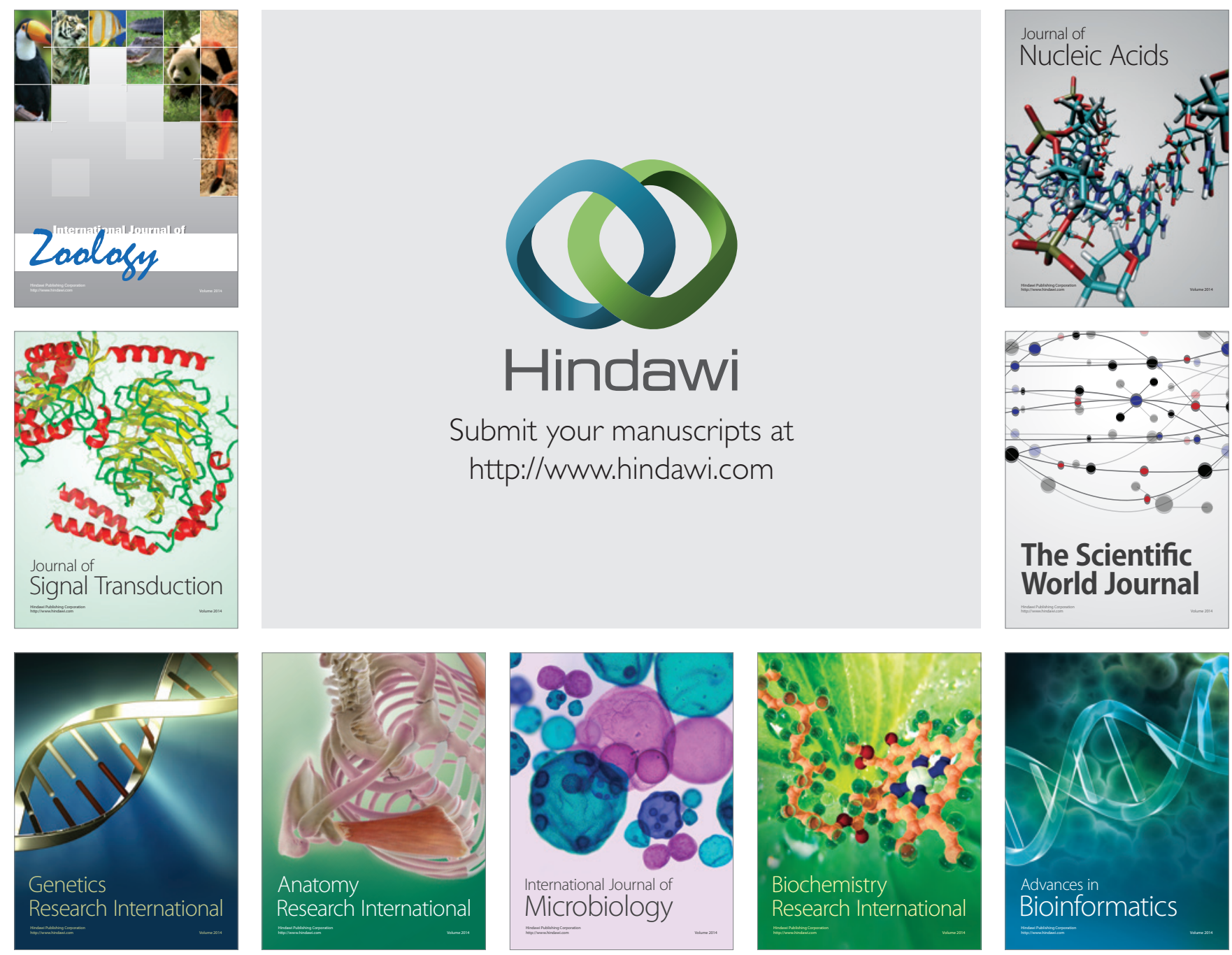

The Scientific World Journal
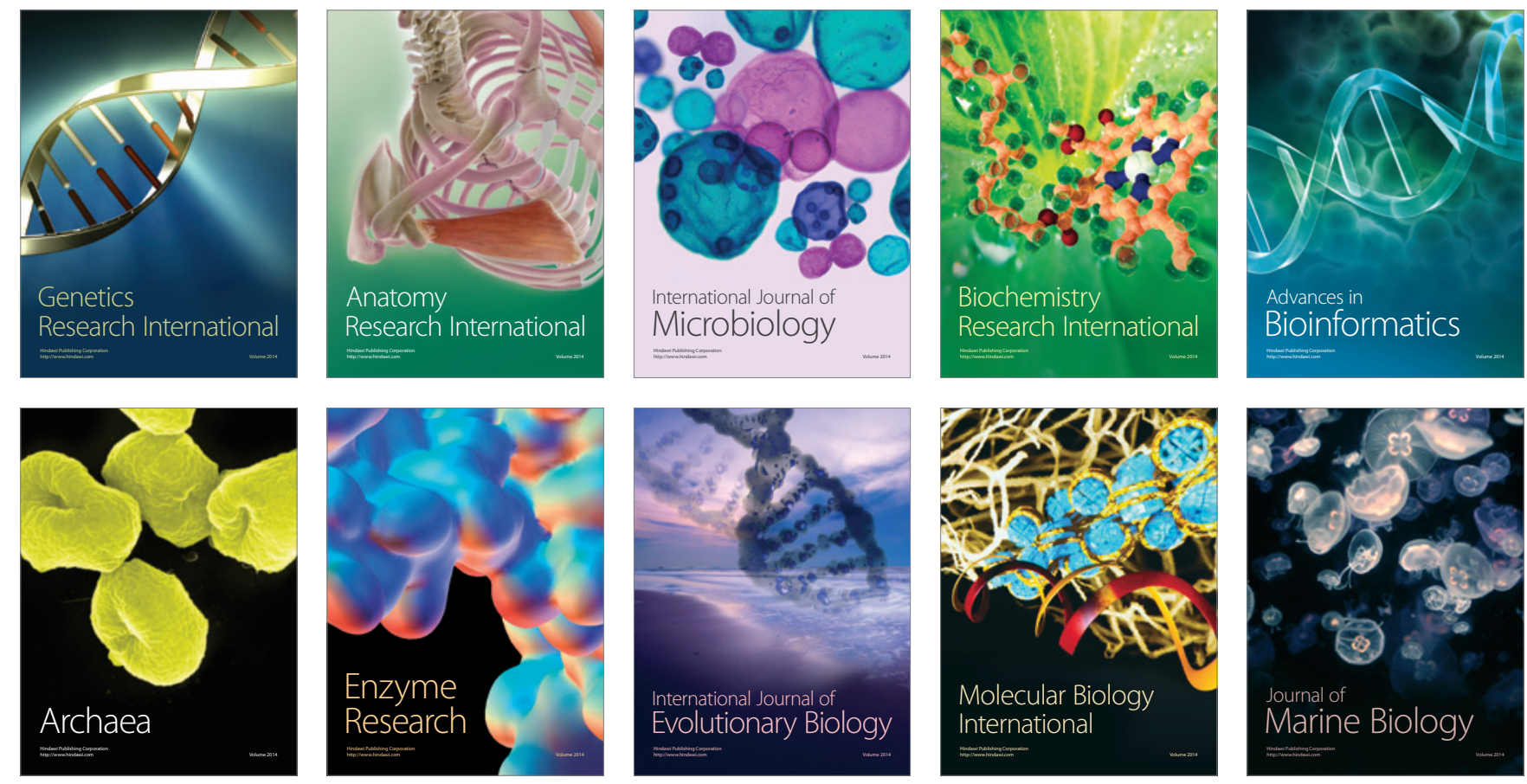